NASA/CR-2004-213086

\title{
Cross Flow Effects on Glaze Ice Roughness Formation
}

Jen-Ching Tsao

Ohio Aerospace Institute, Brook Park, Ohio 
Since its founding, NASA has been dedicated to the advancement of aeronautics and space science. The NASA Scientific and Technical Information (STI) Program Office plays a key part in helping NASA maintain this important role.

The NASA STI Program Office is operated by Langley Research Center, the Lead Center for NASA's scientific and technical information. The NASA STI Program Office provides access to the NASA STI Database, the largest collection of aeronautical and space science STI in the world. The Program Office is also NASA's institutional mechanism for disseminating the results of its research and development activities. These results are published by NASA in the NASA STI Report Series, which includes the following report types:

- $\quad$ TECHNICAL PUBLICATION. Reports of completed research or a major significant phase of research that present the results of NASA programs and include extensive data or theoretical analysis. Includes compilations of significant scientific and technical data and information deemed to be of continuing reference value. NASA's counterpart of peerreviewed formal professional papers but has less stringent limitations on manuscript length and extent of graphic presentations.

- TECHNICAL MEMORANDUM. Scientific and technical findings that are preliminary or of specialized interest, e.g., quick release reports, working papers, and bibliographies that contain minimal annotation. Does not contain extensive analysis.

- CONTRACTOR REPORT. Scientific and technical findings by NASA-sponsored contractors and grantees.
- CONFERENCE PUBLICATION. Collected papers from scientific and technical conferences, symposia, seminars, or other meetings sponsored or cosponsored by NASA.

- SPECIAL PUBLICATION. Scientific, technical, or historical information from NASA programs, projects, and missions, often concerned with subjects having substantial public interest.

- TECHNICAL TRANSLATION. Englishlanguage translations of foreign scientific and technical material pertinent to NASA's mission.

Specialized services that complement the STI Program Office's diverse offerings include creating custom thesauri, building customized databases, organizing and publishing research results ... even providing videos.

For more information about the NASA STI Program Office, see the following:

- Access the NASA STI Program Home Page at http://www.sti.nasa.gov

- E-mail your question via the Internet to help@sti.nasa.gov

- Fax your question to the NASA Access Help Desk at 301-621-0134

- Telephone the NASA Access Help Desk at 301-621-0390

- Write to:

NASA Access Help Desk

NASA Center for AeroSpace Information 7121 Standard Drive

Hanover, MD 21076 
NASA/CR—2004-213086

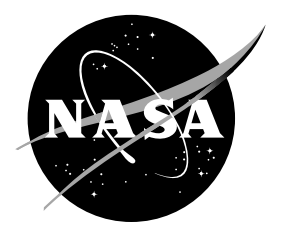

\section{Cross Flow Effects on Glaze Ice Roughness Formation}

Jen-Ching Tsao

Ohio Aerospace Institute, Brook Park, Ohio

Prepared for the

41st Aerospace Sciences Meeting and Exhibit

sponsored by the American Institute of Aeronautics and Astronautics

Reno, Nevada, January 6-9, 2003

Prepared under Cooperative Agreement NCC3-938

National Aeronautics and

Space Administration

Glenn Research Center 


\section{Acknowledgments}

This work was supported under a grant from NASA to the Ohio Aerospace Institute. The author wishes to thank Tom Bond and Mark Potapczuk of the Icing Branch at NASA Glenn Research Center for their support of this study.

This report contains preliminary

findings, subject to revision as

analysis proceeds.

Available from

NASA Center for Aerospace Information 7121 Standard Drive

Hanover, MD 21076
National Technical Information Service 5285 Port Royal Road

Springfield, VA 22100 


\title{
Cross Flow Effects on Glaze Ice Roughness Formation
}

\author{
Jen-Ching Tsao \\ Ohio Aerospace Institute \\ Brook Park, Ohio 44142
}

\begin{abstract}
$\underline{\text { Abstract }}$
The present study examines the impact of largescale cross flow on the creation of ice roughness elements on the leading edge of a swept wing under glaze icing conditions. A three-dimensional tripledeck structure is developed to describe the local interaction of a 3D air boundary layer with ice sheets and liquid films. A linear stability analysis is presented here. It is found that, as the sweep angle increases, the local icing instabilities enhance and the most linearly unstable modes are strictly three dimensional.
\end{abstract}

\section{$\underline{\text { Nomenclature }}$}

$\mathrm{T}_{\mathrm{m}} \quad$ bulk freezing temperature, $273^{\circ} \mathrm{K}$ for water

$\gamma_{s l} \quad$ solid-liquid surface tension

$\gamma_{l v} \quad$ liquid-vapor surface tension

$\mathrm{H}_{s l} \quad$ latent heat of freezing per unit mass of ice

$\mathrm{H}_{l v} \quad$ latent heat of evaporation per unit mass of water

Q density

$c_{p} \quad$ specific heat

$\mathrm{k}$ thermal conductivity

$\alpha \quad$ thermal diffusivity

$\mu \quad$ dynamic viscosity

$\theta_{\mathrm{m}} \quad$ density ratio, $=1-\left(\mathrm{Q}_{l} / \mathrm{\varrho}_{s}\right)$

LWC liquid water content of impinging droplets

$\beta(s) \quad$ local collection efficiency

$x \quad$ sum of the principal curvatures of the interface

$\mathrm{U}_{\infty}$ ambient airspeed

$\mathrm{T}_{\infty} \quad$ ambient air temperature and airspeed

$\mathrm{P}_{\infty} \quad$ ambient air pressure

$\mathrm{L}_{\mathrm{ref}}$ characteristic length scale

$\Delta \mathrm{T}$ freestream supercooling, $=\mathrm{T}_{\mathrm{m}}-\mathrm{T}_{\infty}$

$\mathrm{M}_{\infty} \quad$ freestream Mach number

Pr Prandtl number of air, $=0.72$

$\mathrm{Re}$ freestream Reynolds number, $=\varrho_{\infty} \mathrm{U}_{\infty} \mathrm{L} / \mu_{\infty}$

Ste Stefan number, $=\mathrm{c}_{\mathrm{p}, s} \Delta \mathrm{T} / \mathrm{H}_{s l}$

Sc $\quad$ Schmidt number, $=\mu / \mathrm{Q} D_{A B}$

$D_{A B} \quad$ mass diffusivity coefficient

M relative molecular mass

No viscosity ratio of water to air

$\mathrm{P}_{\mathrm{V}} \quad$ saturated vapor pressure of pure water
$(\mathrm{U}, \mathrm{T})_{\mathrm{e}}$ inviscid surface velocity / temperature

$(\mathrm{s}, \mathrm{N})$ boundary layer scaled coordinates

$(\mathrm{u}, \mathrm{v})_{\mathrm{B}}$ boundary layer scaled velocity components

$(\mathrm{p}, \mathrm{T})_{\mathrm{B}}$ boundary layer scaled pressure / temperature

$\mathrm{h}_{0}(\mathrm{~s}, \mathrm{t})$ boundary layer scaled water film thickness

$\delta_{0}(\mathrm{~s}, \mathrm{t})$ boundary layer scaled ice sheet thickness

$(\mathrm{X}, \mathrm{Y})$ local triple deck scaled coordinates

$(\mathrm{U}, \mathrm{V})$ triple deck scaled velocity components

$(\mathrm{P}, \mathrm{T})$ triple deck scaled pressure / temperature

$\mathrm{h}(\mathrm{X}, \mathrm{t})$ triple deck scaled water film thickness

$\delta(X, t)$ triple deck scaled ice sheet thickness

$v_{\text {imp }}$ scaled impingement velocity

$\delta_{\text {wall }}$ boundary layer scaled wall layer thickness

$\mathrm{T}_{\mathrm{w}, \mathrm{s}} \quad$ scaled steady state inner wall temperature

$t_{0}$ dimensionless global time

$\mathrm{t}$ dimensionless local triple deck time

d roughness element diameter

$\mathrm{R}$ airfoil leading-edge nose radius

$\mathrm{A}_{\mathrm{c}}$ accumulation parameter, dimensionless

$\mathrm{n}$ freezing fraction, dimensionless

Subscripts

$\infty \quad$ in the freestream air

$l \quad$ in the liquid water region

$s \quad$ in the frozen ice layer

$\mathrm{w}$ in the airfoil surface metal wall region

\section{Superscript}

* dimensional quantity

\section{Introduction}

This work analyzes the linear stability of a three-dimensional laminar boundary layer flowing past a thin layer of surface water, formed and replenished from the impingement of small supercooled droplets, on a growing glaze ice substrate near the leading edge of a wing surface with the presence of significant cross flow. Specifically flow over a swept wing is considered, as shown in Fig. 1. Recent experimental investigations on glaze ice shape formation on swept wings ${ }^{1-4}$ have shown that the sweep of a wing can affect the glaze ice accretion process. Figures 2 and 3 are front-view images of a portion of the wing leading edge after approximately $1 \mathrm{~min}$ ute of ice accretion under similar icing conditions, 
with $n=0.41$ and 0.43 respectively. Clearly the induced cross flow on swept wings has changed and modified the surface water run-back behavior, relative to the zero sweep configuration, and consequently the glaze ice accretion process is changed as well. One of the most noticable difference between Figs. 2 and 3 is the replacement of a smooth zone (i.e. $2 \mathrm{D}$ dominant modes with diminishing growth rate) with well defined 3D roughness field along the attachment line (or the stagnation line) region when the wing is swept.

In a previous study on the formation of ice roughness on a NACA 0012 airfoil leading edge under glaze icing conditions, Tsao \& Rothmayer ${ }^{5}$ showed that a mutual interaction between the film dynamics and the ice accretion process can lead to the creation of surface ice roughness elements. The linear stability analysis has predicted that the most unstable and fastest growing modes have streamwise wavelength of millimeter size, and also there is a narrow region of strong instability centered at some distance downstream of the nose. Although qualitative features of glaze ice roughness formation on an airfoil leading edge observed experimentally ${ }^{6-7}$ are well captured by the 2D model, its usefulness in helping one to understand the aforementioned change in roughness formation mechanism associated with swept wings is then limited because the flow is 3D, even if only weakly so. Therefore, a fully three-dimensional triple-deck model is used to study the effect of cross flow on local icing instabilities leading to the formation of glaze ice roughness.

The second area of interest of the paper concerns the possible connection between the Messinger freezing fraction and the icing instability. The Messinger model in its original form represents an equilibrium energy balance, in which the freezing fraction indicates how much super-cooled water droplets upon impact will turn into ice mass in the equilibrium steady state. Its numerical value, ranging from 0 to 1 , determine the physical appearance of the accreted ice. But why does this parameter have such a morphological feature? Is it related to the dynamic aspect of the icing process? As a starting effort, a theoretical derivation of the freezing fraction expression within the context of the current model is made, and it is found that the freezing fraction is directly tied to the samll scale icing instability. A brief discussion of its implication will be given.

\section{The Nonlinear 3D Triple-Deck Flow}

Tsao \& Rothmayer in Ref. 5 have laid out a complete derivation of the overall asymptotic structures for a 2D airfoil glaze icing problem, which includes global boundar-layer and local triple-deck scaled structures. As for the 3D counterpart problem, i.e. flow over a swept wing, the asymptotic scaling analysis given in Ref. 5 can be readily applied. Unfortunately, space does not permit a full discussion and so the paper will focus only on the local flow structures which are important to the glaze ice roughness formation process.

In describing the local flow, a Cartesian coordinate system $(\mathrm{x}, \mathrm{y}, \mathrm{z})$ and their corresponding velocities $(\mathrm{u}, \mathrm{v}, \mathrm{w})$ are taken to be centered at some point on the wing surface, see Fig. 1. The local near-wall streamline (for $\mathrm{y} \rightarrow 0$ ) defines the streamwise direction, $\mathrm{x}$, to which the crossflow direction, $\mathrm{z}$ is normal, and y denotes the coordinate which is perpendicular to and out of the wing surface. Notice that the angle between the local streamwise direction and the global chordwise direction is the flow angle $\theta$, where

$$
\theta=\tan ^{-1}\left(\mathrm{U}_{\mathrm{s}} / \mathrm{U}_{\mathrm{c}}\right) .
$$

Here the subscripts $\mathrm{c}$ and $\mathrm{s}$ indicate the chordwise and spanwise directions respectively. Also, it should be noted that the present analysis neglects possible surface curvature effects, which is generally acceptable in the thin layer model considered here but may fail in other situations.

As shown in Fig. 4, the local air flow is a steady three-dimensional tripl-deck structure. The basic equations and boundary conditions governing the local 3D triple-deck flow is similar to the $2 \mathrm{D}$ case derived in Ref. 5 (i.e. the problem in the z-direction is essentially a mirror image of the problem in the $\mathrm{x}$-direction provided finite boundary-layer scaled wall shear stressess and edge velocities) and will simply be stated here. Interested readers are referred to that study, and some related detailsof 3D boundary layer instability problem may be found in Stewart \& Smith $^{8}$ and Ryzhov \& Terent'ev ${ }^{9}$.

Let us further confine ourselves to the lower nearwall viscous sublayer (lower-deck) where the air flow can affect the growth dynamics of the water 
film and ice layer. The governing equations for the local triple-deck structure are given in Prandtl transposed variables by

$$
\begin{gathered}
\mathrm{U}_{\mathrm{X}}+\mathrm{V}_{\mathrm{Y}}+\mathrm{W}_{\mathrm{Z}}=0 \\
\mathrm{UU}_{\mathrm{X}}+\mathrm{VU}_{\mathrm{Y}}+\mathrm{WU}_{\mathrm{Z}}=-\mathrm{P}_{\mathrm{X}}+\mathrm{U}_{\mathrm{YY}} \\
\mathrm{UW}_{\mathrm{X}}+\mathrm{VW}_{\mathrm{Y}}+\mathrm{WW}_{\mathrm{Z}}=-\mathrm{P}_{\mathrm{Z}}+\mathrm{W}_{\mathrm{YY}}
\end{gathered}
$$

and

$$
\mathrm{UT}_{\mathrm{X}}+\mathrm{VT}_{\mathrm{Y}}+\mathrm{WT}_{\mathrm{Z}}=\operatorname{Pr}^{-1} \mathrm{~T}_{\mathrm{YY}}
$$

with the boundary conditions

$\mathrm{U}(\mathrm{X}, 0, \mathrm{Z})=\mathrm{V}(\mathrm{X}, 0, \mathrm{Z})=\mathrm{W}(\mathrm{X}, 0, \mathrm{Z})=0$,

$\mathrm{T}(\mathrm{X}, 0, \mathrm{Z})=\left[\frac{\mathrm{k}_{\infty}}{\mathrm{k}_{l}}\left(\mathrm{~T}_{\mathrm{Y}}(\mathrm{X}, 0, \mathrm{Z})-\tilde{\mathrm{E}}\right)+\tilde{\mathrm{H}} \mathrm{v}_{\mathrm{imp}}\right] \times$

$$
(\mathrm{h}(\mathrm{X}, \mathrm{Z}, \mathrm{t})-\delta(\mathrm{X}, \mathrm{Z}, \mathrm{t}))+\Gamma\left(\delta_{\mathrm{XX}}+\delta_{\mathrm{ZZ}}\right)
$$

and the farfield matching conditions

$$
\begin{aligned}
& \mathrm{U} \rightarrow \lambda_{\mathrm{X}}\left(\mathrm{Y}+\mathrm{h}-\mathrm{h}_{0}+\mathrm{A}(\mathrm{X}, \mathrm{Z})\right) \text { as } \mathrm{Y} \rightarrow \infty \text {, } \\
& \mathrm{W} \rightarrow \lambda_{\mathrm{Z}}\left(\mathrm{Y}+\mathrm{h}-\mathrm{h}_{0}+\mathrm{A}(\mathrm{X}, \mathrm{Z})\right) \quad \text { as } \mathrm{Y} \rightarrow \infty \text {, } \\
& \mathrm{T} \rightarrow \mathrm{q}\left[\mathrm{Y}+\mathrm{h}-\mathrm{h}_{0}+\mathrm{A}(\mathrm{X}, \mathrm{Z})\right. \\
& \left.+\frac{\mathrm{k}_{\infty}}{\mathrm{k}_{l}} \Theta\left(\mathrm{h}_{0}-\delta_{0}\right)\right], \quad \text { as } \quad \mathrm{Y} \rightarrow \infty
\end{aligned}
$$

where $\lambda_{X}$ and $\lambda_{Z}$ denote the local boundary layer wall shears, $q$ is the local boundary layer surface heat transfer, $\left(h_{0}, \delta_{0}\right)$ represent the boundary layer scaled water film and ice sheet thickness and

$$
\begin{aligned}
& \Theta=1+\frac{\mathrm{k}_{l} \tilde{\mathrm{H}}_{0} \mathrm{v}_{\mathrm{imp}, 0}}{\mathrm{k}_{\infty} \mathrm{q}}-\frac{\tilde{\mathrm{E}}}{\mathrm{q}}, \\
& \tilde{\mathrm{E}} \equiv \mathrm{Re}^{-1 / 2} \frac{\mathrm{H}_{l v} m_{\text {evap }}^{*} \mathrm{~L}_{\text {ref }}}{\mathrm{k}_{\infty} \Delta \mathrm{T}}, \\
& m_{\text {evap }}^{*}=\frac{\mathrm{h}_{\mathrm{c}}}{\mathrm{c}_{\mathrm{p}, \infty}}\left(\frac{\mathrm{Pr}}{\mathrm{Sc}}\right)^{\frac{2}{3}}\left(\frac{\mathbf{M}_{\mathrm{w}}}{\mathbf{M}_{\mathrm{a}}}\right)\left[\frac{\mathrm{P}_{\mathrm{v}, \mathrm{s}}-\mathrm{H}_{\mathrm{r}}\left(\frac{\mathrm{P}_{\mathrm{e}}^{*}}{\mathrm{P}_{\infty}^{*}}\right) \mathrm{P}_{\mathrm{v}, \infty}}{\mathrm{P}_{\mathrm{e}}^{*}}\right] \text {, } \\
& \tilde{\mathrm{H}}_{0} \equiv \operatorname{Re}^{-2 / 8} \mathcal{N}^{-1} \operatorname{Pr}\left(\frac{\rho_{l} \mathrm{k}_{\infty}}{\rho_{\infty} \mathrm{k}_{l}}\right)\left[\frac{\mathrm{U}_{\infty}^{2}}{2 \mathrm{c}_{\mathrm{p}, \infty} \Delta \mathrm{T}}-\frac{\mathrm{c}_{\mathrm{p}, l}}{\mathrm{c}_{\mathrm{p}, \infty}}\right] \text {, } \\
& \left(\mathrm{v}_{\text {imp }}, \mathrm{v}_{\text {evap }}\right)_{0}=\operatorname{Re}^{6 / 8} \mathcal{N}\left(\frac{\mathrm{LWC}}{\rho_{l}} \beta, \frac{m_{\text {evap }}^{*}}{\rho_{l} \mathrm{U}_{\infty}}\right), \\
& \tilde{\mathrm{H}} \equiv \operatorname{Re}^{1 / 8} \mathcal{N}^{-1} \operatorname{Pr}\left(\frac{\rho_{l} \mathrm{k}_{\infty}}{\rho_{\infty} \mathrm{k}_{l}}\right)\left[\frac{\mathrm{U}_{\infty}^{2}}{2 \mathrm{c}_{\mathrm{p}, \infty} \Delta \mathrm{T}}-\frac{\mathrm{c}_{\mathrm{p}, l}}{\mathrm{c}_{\mathrm{p}, \infty}}\right], \\
& \left(\mathrm{v}_{\text {imp }}, \mathrm{v}_{\text {evap }}\right)=\operatorname{Re}^{3 / 8} \mathcal{H}\left(\frac{\mathrm{LWC}}{\rho_{l}} \beta, \frac{m_{\text {evap }}^{*}}{\rho_{l} \mathrm{U}_{\infty}}\right) .
\end{aligned}
$$

The viscosity ratio of water to air, $\mathcal{N}$, is assumed to be large so that the lubrication approximation can be used to describe the film flow.
The unknown displacement function, $\mathrm{A}(\mathrm{X}, \mathrm{Z})$, is related to the self-induced air pressure through the Cauchy-Hilbert integral:

$\mathrm{P}(\mathrm{X}, \mathrm{Z})=\frac{-1}{2 \pi} \int_{-\infty}^{\infty} \frac{\left(\mathrm{U}_{\mathrm{e}} \partial / \partial \xi+\mathrm{W}_{\mathrm{e}} \partial / \partial \eta\right)^{2} \mathrm{~d} \xi \mathrm{d} \eta}{\left[(\mathrm{X}-\xi)^{2}+(\mathrm{Z}-\eta)^{2}\right]^{1 / 2}}$.

The $\mathrm{U}_{\mathrm{e}}$ and $\mathrm{W}_{\mathrm{e}}$ stand for the velocities just outside the boundary layer. The Gibbs-Thomson parameter $\Gamma$, shown in eqn. (22), comes from the GibbsThomson relation and is defined as

$$
\Gamma \equiv \frac{\gamma_{\mathrm{sl}} \mathrm{T}_{\mathrm{m}} \mathrm{Re}^{1 / 4}}{\rho_{\mathrm{s}} \mathrm{H}_{\mathrm{sl}} \Delta \mathrm{T} \mathrm{L}_{\mathrm{ref}}}=\frac{\mathrm{d}_{0}}{\mathrm{~L}_{\mathrm{ref}}}
$$

where $\mathrm{d}_{0}$ is a capillary length defined by

$$
\mathrm{d}_{0} \equiv \frac{\gamma_{\mathrm{sl}} \mathrm{T}_{\mathrm{m}} \mathrm{Re}^{1 / 4}}{\rho_{\mathrm{s}} \mathrm{H}_{\mathrm{s} l} \Delta \mathrm{T}}
$$

The local water film motion and ice layer growth are nonlinearly coupled and governed by

$$
\begin{aligned}
\overline{\mathrm{h}}_{\mathrm{t}} & +\frac{\partial}{\partial \mathrm{X}}\left[\mathrm{U}_{\mathrm{Y}}(\mathrm{X}, 0, \mathrm{Z}) \frac{\tilde{\mathrm{h}}^{2}}{2}-\left(\tilde{\mathrm{P}}_{\mathrm{X}}+\tilde{\mathrm{G}}_{\mathrm{X}} \sin \theta_{\mathrm{X}}\right) \frac{\tilde{\mathrm{h}}^{3}}{3}\right] \\
& +\frac{\partial}{\partial \mathrm{Z}}\left[\mathrm{W}_{\mathrm{Y}}(\mathrm{X}, 0, \mathrm{Z}) \frac{\tilde{\mathrm{h}}^{2}}{2}-\left(\tilde{\mathrm{P}}_{\mathrm{Z}}+\tilde{\mathrm{G}}_{\mathrm{Z}} \sin \theta_{\mathrm{Z}}\right) \frac{\tilde{\mathrm{h}}^{3}}{3}\right] \\
& =\mathrm{v}_{\text {imp }}-\mathrm{v}_{\text {evap }}
\end{aligned}
$$

and

$$
\begin{aligned}
& \mathrm{S}_{1} \operatorname{Pr}\left(\frac{\alpha_{\infty}}{\alpha_{s}}\right) \frac{\partial \delta}{\partial \mathrm{t}}=\frac{\mathrm{k}_{\mathrm{w}}}{\mathrm{k}_{s}}\left(\frac{1-\mathrm{T}_{\mathrm{w}, \mathrm{s}}}{\delta_{\mathrm{wall}}}\right) \\
& -\frac{\mathrm{k}_{l}}{\mathrm{k}_{s}}\left(\frac{\mathrm{k}_{\infty}}{\mathrm{k}_{l}}\left(\mathrm{~T}_{\mathrm{Y}}(\mathrm{X}, 0, \mathrm{Z})-\tilde{\mathrm{E}}\right)+\tilde{\mathrm{H}} \mathrm{v}_{\mathrm{imp}}\right)
\end{aligned}
$$

where $\overline{\mathrm{h}}=\mathrm{h}-\theta_{\mathrm{m}} \delta, \tilde{\mathrm{h}}=\mathrm{h}-\delta$ and

$$
\begin{gathered}
\tilde{\mathrm{P}}_{\mathrm{X}}=\mathrm{P}_{\mathrm{X}}-\tilde{\mathrm{T}}(\Delta \mathrm{h})_{\mathrm{X}}+\tilde{\mathrm{G}}_{\mathrm{Y}}\left(\cos \theta_{\mathrm{X}}+\cos \theta_{\mathrm{Z}}\right) \mathrm{h}_{\mathrm{X}} \\
\tilde{\mathrm{P}}_{\mathrm{Z}}=\mathrm{P}_{\mathrm{Z}}-\tilde{\mathrm{T}}(\Delta \mathrm{h})_{\mathrm{Z}}+\tilde{\mathrm{G}}_{\mathrm{Y}}\left(\cos \theta_{\mathrm{X}}+\cos \theta_{\mathrm{Z}}\right) \mathrm{h}_{\mathrm{Z}}
\end{gathered}
$$

with

$$
\Delta \mathrm{h} \equiv \mathrm{h}_{\mathrm{XX}}+\mathrm{h}_{\mathrm{ZZ}}
$$

The gravitational and surface tension parameters of liquid water are defined as

$$
\begin{aligned}
\left(\tilde{\mathrm{G}}_{\mathrm{X}, \mathrm{Z}}, \tilde{\mathrm{G}}_{\mathrm{Y}}\right) & =\left(\operatorname{Re}^{-1 / 8}, \operatorname{Re}^{-3 / 8}\right)\left(\rho_{l}\right)\left(\frac{\mathrm{gL}}{\mathrm{U}_{\infty}^{2}}\right) \\
& =\left(\operatorname{Re}^{-17 / 8}, \operatorname{Re}^{-19 / 8}\right)\left(\rho_{l} \rho_{\infty} \mathrm{gL}^{3} / \mu_{\infty}^{2}\right)
\end{aligned}
$$

and

$$
\tilde{\mathrm{T}}=\operatorname{Re}^{-13 / 8}\left(\rho_{\infty} \gamma_{l v} \mathrm{~L} / \mu_{\infty}^{2}\right) .
$$

Also in the Stefan equation, i.e. eqn. (14), the triple-deck scaled Stefan number is defined as 


$$
\mathrm{S}_{1}=\operatorname{Re}^{1 / 8}(\mathcal{N} \text { Ste })^{-1}
$$

where

$$
\text { Ste } \equiv \frac{\mathrm{c}_{\mathrm{p}, s} \Delta \mathrm{T}}{\mathrm{H}_{\mathrm{s} l}}, \quad \mathrm{Re} \equiv \frac{\rho_{\infty} \mathrm{U}_{\infty} \mathrm{L}_{\mathrm{ref}}}{\mu_{\infty}} .
$$

\section{Linear Stability Analysis}

As in the studies of Smith ${ }^{10}$ and others $5,11,12$, the flow is resolved into its primary and perturbation parts. Although we are considering only the leading order term, Smith ${ }^{10}$ shows that high order terms could be added to improve the accuracy of the solution. The variables are expanded in normal mode form as follows:

$(\mathrm{U}, \mathrm{V}, \mathrm{W}, \mathrm{P}, \hat{\mathrm{P}}, \mathrm{T}, \mathrm{A}, \mathrm{h}, \delta)=\left(\lambda_{\mathrm{X}} \mathrm{Y}, 0, \lambda_{\mathrm{Z}} \mathrm{Y}, 0,0\right.$,

$\mathrm{q}\left[\mathrm{Y}+\frac{\mathrm{k}_{\infty}}{\mathrm{k}_{l}} \Theta\left(\mathrm{h}_{0}-\delta_{0}\right)\right], 0, \mathrm{~h}_{0}, \delta_{0}+\epsilon(\overline{\mathrm{U}}(\mathrm{Y})$,

$\overline{\mathrm{V}}(\mathrm{Y}), \overline{\mathrm{W}}(\mathrm{Y}), \overline{\mathrm{P}}, \overline{\overline{\mathrm{P}}}(\overline{\mathrm{y}}), \overline{\mathrm{T}}(\mathrm{Y}), \overline{\mathrm{A}}, \overline{\mathrm{h}}, \bar{\delta}) \mathrm{e}^{\mathrm{i}\left(k_{\mathrm{x}} \mathrm{X}+k_{\mathrm{z}} \mathrm{Z}\right)+\omega \mathrm{t}}$,

where $k_{\mathrm{x}}$ and $k_{\mathrm{Z}}$ (both are real) denote the tripledeck scaled wave numbers in $\mathrm{X}$ and $\mathrm{Z}$ directions and $\left(l^{*}\right)_{\mathrm{X}, \mathrm{Z}}=2 \pi /\left(k_{\mathrm{X}}, k_{\mathrm{Z}}\right)^{*}=2 \pi \mathrm{L}_{\mathrm{TD}} /\left(k_{\mathrm{X}}, k_{\mathrm{Z}}\right)$ are the associated disturbance wavelengths (here $\mathrm{L}_{\mathrm{TD}}=$ $\left.\mathrm{Re}^{-3 / 8} \mathrm{~L}_{\mathrm{ref}}\right)$. The triple-deck scaled frequency $\omega$ is complex, $\omega=\omega_{r}+i \omega_{i}$, and may be readily related to the well-known complex wave speed, $c=c_{r}+i$ $c_{i}$, where $c=\omega /(-i k)$ with $k^{2}=k_{\mathrm{x}}^{2}+k_{\mathrm{z}}^{2}$. As usual, $c_{r}$ is the phase speed of the wave, whereas $c_{i}$ determines the degree of damping (if $c_{i}<0, \omega_{r}<0$ ), or amplification (if $c_{i}>0, \omega_{r}>0$ ).

The three-dimensional linear stability problem can be further reduced to an equivalent two-dimensional problem if one lets

$$
\begin{gathered}
k^{2}=k_{\mathrm{x}}^{2}+k_{\mathrm{Z}}^{2}, \quad k \mathrm{U}=k_{\mathrm{X}} \overline{\mathrm{U}}+k_{\mathrm{Z}} \overline{\mathrm{W}}, \\
k \lambda=k_{\mathrm{X}} \lambda_{\mathrm{X}}+k_{\mathrm{Z}} \lambda_{\mathrm{Z}}, \quad k \mathrm{Ue}=k_{\mathrm{X}} \mathrm{U}_{\mathrm{e}}+k_{\mathrm{Z}} \mathrm{W}_{\mathrm{e}} \\
\cos \theta=\cos \theta_{\mathrm{X}}+\cos \theta_{\mathrm{Z}}, \\
k \mathrm{G} \sin \theta=k_{\mathrm{X}} \tilde{\mathrm{G}}_{\mathrm{X}} \sin \theta_{\mathrm{X}}+k_{\mathrm{Z}} \tilde{\mathrm{G}}_{\mathrm{Z}} \sin \theta_{\mathrm{Z}} \\
\mathrm{V}=\overline{\mathrm{V}}, \quad \mathrm{T}=\overline{\mathrm{T}}, \quad \text { and } \mathrm{P}=\overline{\mathrm{P}} .
\end{gathered}
$$

The ensuing quadratic dispersion relation for the linear instability eigenvalues, i.e. $\omega$, is found to be $\left(\gamma \beta \mathrm{L}_{0}\right) \omega^{2}+\left(\Lambda \beta-\theta_{\mathrm{m}} \mathrm{N}_{0} \mathrm{~L}_{0}+\mathrm{e}_{1} \gamma \mathrm{L}_{0}\right) \omega$

$+\left(\Lambda \mathrm{e}_{1}-\mathrm{N}_{0} \mathrm{~L}_{0} \mathrm{e}_{2}-\mathrm{M}_{\mathrm{v}}\right)=0$,

where
$\Lambda=\bar{\Lambda}\left[\mathrm{q} \Theta+\frac{\mathrm{k}_{l}}{\mathrm{k}_{\infty}} \Gamma k^{2}\right], \quad \gamma=-\frac{\mathrm{k}_{s} \alpha_{\infty} \mathrm{S}_{1} \mathrm{Pr}}{\mathrm{k}_{\infty} \alpha_{s} \overline{\bar{\theta}}}$,

$\bar{\Lambda}=\left(1-\frac{\Phi_{1}}{\mathrm{k}_{\infty}}\right) \mathrm{Ai}^{\prime}(0)-\frac{\Phi_{2}}{\overline{\bar{\theta}} \mathrm{k}_{\infty}} \operatorname{Ai}(0)$,

$\beta=\frac{\mathrm{e}^{\mathrm{i} \pi / 6} k^{1 / 3}|k| \mathrm{Ue}^{2}}{3 \lambda^{5 / 3} \mathrm{Ai}^{\prime}(0)}-1$,

$\mathrm{L}_{0}=\mathrm{L}_{1} \operatorname{Ai}(0)-\mathrm{L}_{2} \mathrm{Ai}^{\prime}(0)$,

$\mathrm{L}_{1}=\frac{\mathrm{k}_{l}}{\mathrm{k}_{\infty}}+\frac{\Phi_{2}}{\mathrm{k}_{\infty}}\left(\mathrm{h}_{0}-\delta_{0}\right)$

$\mathrm{L}_{2}=\left(1-\frac{\Phi_{1}}{\mathrm{k}_{\infty}}\right) \overline{\bar{\theta}}\left(\mathrm{h}_{0}-\delta_{0}\right)$,

$\mathrm{N}_{0}=\left(1-\frac{\Phi_{1}}{\mathrm{k}_{\infty}}\right) \mathrm{N}_{1}-\frac{\Phi_{2}}{\overline{\bar{\theta}} \mathrm{k}_{\infty}} \mathrm{N}_{2}$,

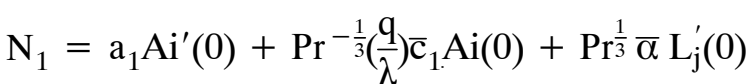
$+\left(\frac{\mathrm{q}}{\lambda}\right) \frac{(\operatorname{Pr}-1)}{\operatorname{Pr}^{\frac{2}{3}}} \overline{\mathrm{c}}_{1} \mathrm{~L}_{\mathrm{k}}^{\prime}(0)$,

$\mathrm{N}_{2}=\mathrm{a}_{1} \operatorname{Ai}(0)+\operatorname{Pr} \frac{1}{3 \alpha} \mathrm{L}_{\mathrm{j}}(0)+\left(\frac{\mathrm{q}}{\lambda}\right) \frac{(\operatorname{Pr}-1)}{\operatorname{Pr}^{\frac{2}{3}}} \overline{\mathrm{c}}_{1} \mathrm{~L}_{\mathrm{k}}(0)$,

$\Phi_{1}=\left(\frac{-\mathrm{H}_{l v}}{\mathrm{c}_{\mathrm{p}, \infty} \Delta \mathrm{T}}\right)\left(\frac{\mathrm{Pr}}{\mathrm{Sc}}\right)^{\frac{2}{3}}\left(\frac{\mathbf{M}_{\mathrm{w}}}{\mathbf{M}_{\mathrm{a}}}\right)\left[\frac{\mathrm{P}_{\mathrm{v}, \mathrm{s}}-\mathrm{H}_{\mathrm{r}}\left(\frac{\mathrm{P}_{\mathrm{e}}^{*}}{\mathrm{P}_{\infty}^{*}}\right) \mathrm{P}_{\mathrm{v}, \infty}}{\mathrm{P}_{\mathrm{e}}^{*}}\right]$,

$\Phi_{2}=\left(\frac{-\mathrm{q} \mathrm{H}_{l v}}{\mathrm{c}_{\mathrm{p}, \infty} \Delta \mathrm{T}}\right)\left(\frac{\mathrm{Pr}}{\mathrm{Sc}}\right)^{\frac{2}{3}}\left(\frac{\mathbf{M}_{\mathrm{w}}}{\mathbf{M}_{\mathrm{a}}}\right)\left[\frac{17.15 \mathrm{P}_{\mathrm{v}, \mathrm{s}} \Delta \mathrm{T}}{\mathrm{P}_{\mathrm{e}}^{*}\left(\mathrm{~T}_{\mathrm{m}}-38.25\right)}\right]$,

$\mathrm{a}_{1}=\mathrm{L}_{0}^{-1}\left\{\mathrm{q} \Theta \beta+\mathrm{L}_{2}\left[\frac{\mathrm{qA}_{\mathrm{i}}(0)}{\lambda \operatorname{Pr}^{\frac{1}{3}}} \overline{\mathrm{c}}_{1}+\operatorname{Pr}^{\frac{1}{3}} \mathrm{~L}_{\mathrm{j}}^{\prime}(0) \bar{\alpha}+\right.\right.$ $\left.\frac{\mathrm{q}(\operatorname{Pr}-1) \mathrm{L}_{\mathrm{k}}^{\prime}(0)}{\lambda \operatorname{Pr}^{\frac{2}{3}}} \overline{\mathrm{c}}_{1}\right]-\mathrm{L}_{1}\left[\operatorname{Pr}^{\frac{1}{3}} \mathrm{~L}_{\mathrm{j}}(0) \bar{\alpha}+\right.$ $\left.\left.+\frac{\mathrm{q}(\operatorname{Pr}-1) \mathrm{L}_{\mathrm{k}}(0)}{\lambda \operatorname{Pr}^{\frac{2}{3}}} \overline{\mathrm{c}}_{1}\right]\right\}$,

$\mathrm{e}_{1}=\mathrm{e}_{3} \beta+\frac{1}{2} \mathrm{i} k\left(\mathrm{~h}_{0}-\delta_{0}\right)^{2} \bar{\theta} \mathrm{A}_{\mathrm{i}}(0) \overline{\mathrm{c}}_{1}+$ $\frac{1}{3} k^{2}\left(\mathrm{~h}_{0}-\delta_{0}\right)^{3} \hat{\mathrm{P}}$,

$\mathrm{e}_{2}=\mathrm{i} k \lambda\left(\mathrm{h}_{0}-\delta_{0}\right)-\mathrm{i} k\left(\mathrm{~h}_{0}-\delta_{0}\right)^{2} \mathrm{G} \sin \theta$,

$\mathrm{e}_{3}=\mathrm{i} k \lambda\left(\mathrm{h}_{0}-\delta_{0}\right)+\frac{1}{3} k^{2}\left(\mathrm{~h}_{0}-\delta_{0}\right)^{3} \tilde{\mathrm{G}}_{\mathrm{Y}} \cos \theta$

$-\mathrm{i} k\left(\mathrm{~h}_{0}-\delta_{0}\right)^{2} \mathrm{G} \sin \theta+\frac{1}{3} k^{4}\left(\mathrm{~h}_{0}-\delta_{0}\right)^{3} \tilde{\mathrm{T}}$,

$\mathrm{M}_{\mathrm{v}}=\mathrm{N}_{0}\left[\mathrm{~A}_{\mathrm{m}} \overline{\bar{\theta}} \mathrm{Ai}^{\prime}(0)+\mathrm{B}_{\mathrm{m}} \mathrm{Ai}(0)\right]\left[\mathrm{q} \Theta+\frac{\mathrm{k}_{l}}{\mathrm{k}_{\infty}} \Gamma k^{2}\right]$, 


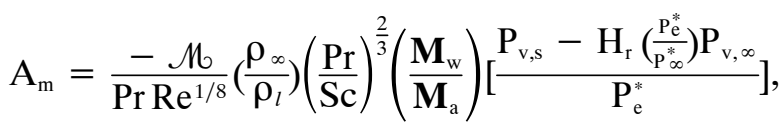

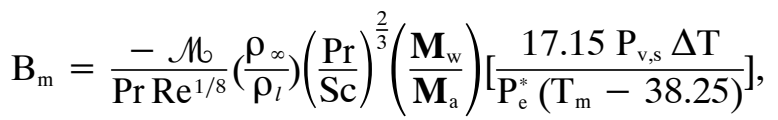

with

$$
\begin{aligned}
& \overline{\mathrm{c}}_{1}=\frac{\mathrm{e}^{\mathrm{i} \pi / 6} k^{1 / 3}|k| \mathrm{Ue}^{2}}{\lambda^{2 / 3} \mathrm{Ai}^{\prime}(0)}, \quad \hat{\mathrm{P}}=|k| \mathrm{Ue}^{2}, \\
& \bar{\alpha}=(\mathrm{q} / \lambda) \frac{\mathrm{e}^{\mathrm{i} \pi / 6} k^{1 / 3}|k| \mathrm{Ue}^{2}}{\lambda^{2 / 3}}
\end{aligned}
$$

and

$$
\bar{\theta}=(k \lambda)^{1 / 3} \mathrm{e}^{\mathrm{i} \pi / 6}, \quad \overline{\bar{\theta}}=(k \lambda \operatorname{Pr})^{1 / 3} \mathrm{e}^{\mathrm{i} \pi / 6} .
$$

It is noted that, in the above expressions, Ai denotes the Airy function of the first kind. Two special functions, $\mathrm{L}_{\mathrm{j}}$ and $\mathrm{L}_{\mathrm{k}}$, are introduced and they satisfy

$$
\mathrm{L}_{\mathrm{j}}^{\prime \prime}-\xi \mathrm{L}_{\mathrm{j}}=-1, \mathrm{~L}_{\mathrm{j}}(\infty)=\mathrm{L}_{\mathrm{j}}^{\prime}(\infty)=0,
$$

and

$\mathrm{L}_{\mathrm{k}}^{\prime \prime}-\xi \mathrm{L}_{\mathrm{k}}=\mathrm{Ai}^{\prime}\left(\operatorname{Pr}^{-\frac{1}{3} \xi}\right), \mathrm{L}_{\mathrm{k}}(\infty)=\mathrm{L}_{\mathrm{k}}^{\prime}(\infty)=0$.

Their numerical solutions at $\xi=0$ are given as follows:

$$
\begin{array}{ll}
\mathrm{L}_{\mathrm{j}}(0)=0.643949, & \mathrm{~L}_{\mathrm{j}}^{\prime}(0)=0.469446, \\
\mathrm{~L}_{\mathrm{k}}(0)=0, & \mathrm{~L}_{\mathrm{k}}^{\prime}(0)=0.169538,
\end{array}
$$

along with

$$
\operatorname{Ai}(0)=0.35502, \quad \mathrm{Ai}^{\prime}(0)=-0.25881 .
$$

A number of parametric studies, based on the test condition given for Fig. 2, are performed to assess the cross flow effects, i.e. via varying $\mathrm{W}_{\mathrm{e}}$ and $\lambda_{\mathrm{Z}}$, on instability. Several important findings are obtained from the results:

(1) There are two types of instabilities, wave-like $\left(\omega_{1}\right)$ and broad-band $\left(\omega_{2}\right)$ modes, both present in the flowfield(see Fig. 5).

(2) The most linearly unstable modes are strictly three-dimensional when the cross flow is present (see Fig. 6).

(3) The instabilities are enhanced with increasing growth rates and wave speeds as the cross flow becomes stronger, see Fig. 7.

(4) There is a considerable change in the most observable instability growing patterns, in terms of the characteristic length scales, when the cross flow is non-zero, see Figs. 8 and 9.

\section{Comparison with Experiments}

As mentioned early in the introduction, this study was partly motivated by the aim to understand the glaze ice roughness formation process on swept wings. To apply the stability analysis, i.e. eqn. (17), to the experimental data of Fig.3, a "quasi 3D" synthetic global flow profile was constructed for points along a given chordwise cross section (i.e. a NACA 0012 airfoil) of a swept wing, see Fig. 10. The combined 3D flow mainly contains a 2D boundary layer solution for flow past the parabolic leading edge of a NACA 0012 airfoil at zero angle of attack with some prescribed spanwise velocity distributions.

Two important observations are noticed from the stability analysis. They are summarized briefly as follows:

(1) The leading edge region is covered entirely with three-dimensional ice roughness elements of different sizes and aspect ratios, see Fig. 11. The "average" characteristic length of the $3 \mathrm{D}$ roughness is about $1 \mathrm{~mm}$. The smooth zone observed in Ref. 7 (see Fig. 2) for zero sweep angle condition has disappeared.

(2) There is a narrow region of strong instability centered at some distance $(\sim 8 \mathrm{~mm})$ downstream of the nose, see Fig. 12. The roughness elements in this zone are expected to grow much faster and larger than roughness elements in other locations. In comparison with our prediction, the critical distance (measured from the attachment line to the beginning of larger glaze ice feather zone) given by Vargas et. al.in Ref. 1 is about $6 \mathrm{~mm}$ after $1 \mathrm{~min}$ of ice accretion.

\section{Connection with the Freezing Fraction}

In icing scaling, the freezing fraction parameter $n$, derived from the Messinger energy-balance analysis for freezing at an unheated surface, can be written in the form ${ }^{13-14}$,

$$
\mathrm{n}=\frac{\mathrm{c}_{\mathrm{p}, l}}{\mathrm{H}_{s, l}}\left(\boldsymbol{\phi}+\frac{\boldsymbol{\theta}}{\mathbf{b}}\right)
$$

The terms involved are $\phi$, the water droplet energy transfer parameter; $\boldsymbol{\theta}$, the air energy transfer parameter; and $\mathbf{b}$, the relative heat factor which was first 
introduced by Tribus et. al. ${ }^{15}$ The analytical forms of these terms are not presented here. Interested readers are referred to Refs. 13 and14. For more recent information, readers are referred to Ref. 16 as well.

Since Messinger's energy-balance analysis does not consider heat loss from water runback or to conduction into the cold wall, ice substrate and water film, the freezing fraction parameter is effectively related to the overall heat transfer parameter of air/ droplet mixture, $\mathrm{q} \Theta$, of the current model. After some working, the freezing fraction can be rewritten as

$$
\mathrm{n}=\left(\mathrm{S}_{0} \operatorname{Pr}\right)^{-1}\left(\frac{\alpha_{l} \mathrm{k}_{\infty}}{\alpha_{\infty} \mathrm{k}_{l}}\right)\left(\frac{\mathrm{c}_{\mathrm{p}, l}}{\mathrm{c}_{\mathrm{p}, s}}\right)\left(\frac{-\mathrm{q} \Theta}{\mathrm{v}_{\mathrm{imp}, 0}}\right) .
$$

A numerical verification of eqn. (19) is carried out by comparing the calculated freezing fraction values at the stagnation point for (laminar) flow over a NACA 0012 airfoil against values given by Refs. 17 and 18 using eqn. (18). The results, given in Fig. 13 , show good agreement consistent over all test conditions.

With this new form for $\mathrm{q} \Theta$, the large scale ice substrate growth rate at a given location on the surface can be rewritten as (see Ref. 5 for derivation)

$$
\begin{aligned}
& \operatorname{Pr}_{0}\left(\frac{\alpha_{\infty}}{\alpha_{\mathrm{S}}}\right) \frac{\partial \delta_{0}}{\partial \mathrm{t}} \\
& \quad=\frac{\Pi}{\mathrm{t}^{1 / 2}}+\left(\frac{\mathrm{k}_{l} \alpha_{\infty}}{\mathrm{k}_{\mathrm{S}} \alpha_{l}}\right)\left(\frac{\mathrm{c}_{\mathrm{p}, \mathrm{s}}}{\mathrm{c}_{\mathrm{p}, l}}\right)\left(\mathrm{S}_{0} \operatorname{Pr} \mathrm{v}_{\mathrm{imp}, 0}\right) \mathrm{n}
\end{aligned}
$$

where

$$
\Pi=\operatorname{Re}^{\frac{11}{16}} \mathcal{M}^{\frac{1}{2}}\left(\frac{\sigma}{\bar{\beta}}\right) \frac{\operatorname{Pr}_{0} \alpha_{\infty}}{\sqrt{\pi \alpha_{s} \mathrm{~L}_{\text {ref }} \mathrm{U}_{\infty}}}
$$

provided that

$$
\begin{aligned}
& \bar{\beta}=\mathrm{H}_{s l} / \mathrm{c}_{\mathrm{p}, s}\left(\mathrm{~T}_{\mathrm{m}}-\mathrm{T}_{\mathrm{w}}(\mathrm{s})\right) \gg 1 ; \\
& \sigma=\left(\mathrm{Q}_{\mathrm{w}} \mathrm{c}_{\mathrm{p}, \mathrm{w}} \mathrm{k}_{\mathrm{w}} / \mathrm{\varrho}_{s} \mathrm{c}_{\mathrm{p}, s} \mathrm{k}_{s}\right)^{1 / 2} \ll \bar{\beta} .
\end{aligned}
$$

The first term on the r.h.s. of eqn. (20) is the transient growth from the cold wall, and the second term is the steady-state growth rate, i.e. as $t \rightarrow \infty$. This suggests that the Messinger model really is a large time asymptote of the current model. Also the dispersion relation of eqn. (17) can be approximated as

$$
\begin{aligned}
& \omega_{1} \sim-\frac{\mathrm{e}_{1}}{\beta}, \quad \Rightarrow \quad(\lambda, \mathrm{Ue}) \leftrightarrow \tilde{\mathrm{T}} \\
& \omega_{2} \sim-\frac{\Lambda}{\gamma \mathrm{L}_{0}}, \quad \Rightarrow \quad(\mathrm{q} \Theta) \leftrightarrow \Gamma
\end{aligned}
$$

via an order of magnitude analysis of the equation. With this expression for $\omega_{2}$, the freezing fraction is directly tied to the broad-band icing mode. Furthermore, by setting $\omega_{2}=0$, the neutral stability wave number $k_{2}$ is found to be

$k_{2}=\sqrt{\left(\frac{\mathrm{n}}{\mathcal{H}_{\mathrm{L}}}\right)\left(\frac{\rho_{l}}{\rho_{\mathrm{S}}}\right)\left(\frac{\alpha_{\infty}}{\alpha_{l}}\right)\left(\frac{\mathrm{c}_{\mathrm{p}, \mathrm{S}}}{\mathrm{c}_{\mathrm{p}, l}}\right) \operatorname{Pr} \mathrm{v}_{\text {imp }, 0}\left(\frac{\mathrm{Re}^{-1 / 2} \mathrm{~L}_{\mathrm{ref}}}{\mathrm{d}_{0}}\right)}$

which gives

$$
\lambda_{2} \sim \sqrt{\frac{\mathrm{L}_{\mathrm{ref}} \mathrm{d}_{0}}{\mathrm{n}}} \sim \mathrm{O}(\mu \mathrm{m})
$$

the smallest unstable ice roughness a physical length scale that is close to an ice feather. In summary, the freezing fraction is found to be an important parameter that can control small scale ice roughness (feather) growth.

\section{Conclusions}

A three-dimensional triple-deck local flow structure is developed to study the impact of large-scale cross flow on the creation of ice roughness elements on the leading edge of a swept wing under glaze icing conditions. A linear stability analysis is performed locally and found that when the cross flow is present, the instabilities enhance and the most linearly unstable growing ice roughness are fully three dimensional.

For glaze icing conditions tested on a NACA 0012 swept wing ${ }^{1-4}$, two important observations are obtained from the stability analysis. First of all, the leading edge region is covered entirely with $3 \mathrm{D}$ ice roughness of mm size. The smooth zone, observed and reported by Anderson ${ }^{7}$, has disappeared. Secondly, there is a narrow region of strong instability located at about $8 \mathrm{~mm}$ away from the nose. The roughness elements in this zone are expected to grow much faster and larger than roughness elements in other locations. In comparison with our prediction, the critical distance (measured from the attachment line to the beginning of larger glaze ice feather zone) given by Vargas et. al.in Ref. 1 is about $6 \mathrm{~mm}$ after $1 \mathrm{~min}$ of ice accretion. 
A connection between the Messinger freezing fraction and the current glaze icing model has been established. This parameter is found to be important for small scale ice roughness (ice feather) growth.

\section{References}

1. Vargas, M. and Reshotko, E., "Physical Mechanisms of Glaze Ice Scallop Formations on Swept Wings", AIAA-98-0491, Jan. 1998.

2. Vargas, M. and Reshotko, E., "Parametric Experimental Study of the Formation of Glaze Ice Shapes on Swept Wings", AIAA-99-0094, Jan. 1999.

3. Vargas, M. and Reshotko, E., "LWC and Temperature Effects on Ice Accretion Formation on Swept Wings at Glaze Ice Conditions", AIAA-2000-04 83, Jan. 2000.

4. Vargas, M., Giriunas, J., Ratvasky, T., "Ice Accretion Formations on a NACA 0012 Swept Wing Tip in Nature Icing Conditions", AIAA -2002-0244, Jan. 1998.

5. Tsao, J.C. and Rothmayer, A.P., "Application of Triple-Deck Theory to the Prediction of Glaze Ice Roughness Formation on an Airfoil Leading Edge" , Computers \& Fluids, 31 (2002), pp. 977-1014 .

6. Shin, J., "Characteristics of Surface Roughness Associated with Leading Edge Ice Accretion," AIAA-94-0799, Jan. 1994.

7. Anderson, D.N., Hentschel, D.B. and Ruff, G.A.," Measurement and Correlation of Ice-Accretion Roughness," AIAA-98-0486, Jan. 1998.

8. Stewart, P. and Smith, F., "Three-Dimensional Instabilities in Steady and Unsteady Non-Parallel Boundary Layers, Including Effects of TollmienSchlichting Disturbances and Cross Flow", Proc. Roy. Soc., A409, pp. 220-248, 1987.
9. Ryzhov, O. and Terent'ev, E., "Nonlinear waves in a Three-Dimensional Boundary Layer", IUTAM symposium on Nonlinear Instability and Transition in Three-Dimensional Boundary Layers, Kluwer Academic Publishers, pp. 167-176, 1996.

10. Smith, F. T., "On the Non-Parallel Flow Stability of the Blasius Boundary-Layer," Proc. Roy. Soc., A366, pp. 91-109, 1979.

11. Tsao, J. C., Rothmayer, A. P. and Ruban, A. I., "Stability of Air Flow Past Thin Liquid Films on Airfoils," Computers and Fluids, Vol. 26 No. 5, pp. 427-452, 1997.

12. Tsao, J.C. and Rothmayer, A.P., "A Mechanism for Ice Roughness Formation on an Airfoil Leading Edge, Contributing to Glaze Ice Accretion," AIAA-98-0485, Jan. 1998.

13. Messinger, B. L., "Equilibrium Temperature of an Unheated Icing Surface as a Function of Airspeed." Journal of the Aeronautical Science, Vol 20, No. 1, pp. 29-42, Jan. 1953.

14. Ruff, G. A., "Analysis and Verification of the icing Scaling Equations", AEDC-TR-85-30, Vol 1 (Rev), March 1986.

15. Anderson, A. N. and Tsao, J. C., "Evaluation and Validation of the Messinger Freezing Fraction”, AIAA-2003-1218, Jan. 2003.

16. Tribus, M., Young, G. and Boelter, L., “Analysis of Heat Transfer Over a Small Cylinder in Icing Conditions on Mt. Washington", Trans. ASME Vol. 70, 1949, pp. 971-976.

17. Anderson, D.N., " A Preliminary Study of IceAccretion Scaling for SLD Conditions," AIAA-2002-0521, Jan. 2002.

18. Anderson, D.N. and Feo, A. "Ice-Accretion Scaling using Water-Film Thickness Parameters," AIAA-2002-0522, Jan. 2002. 


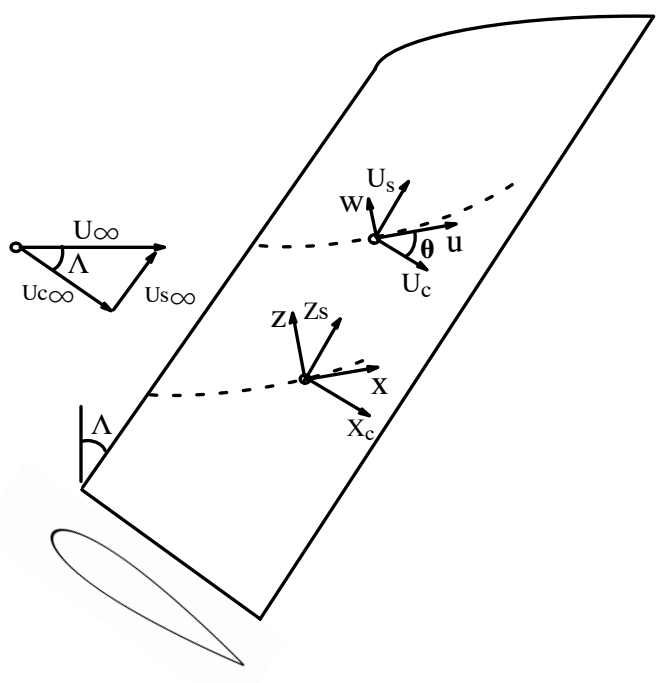

Figure 1: Schematic diagram of the flow geometry and the associated Cartesian coordinate system in which the y-direction is out of the plane. The broken lines represent the surface streamlines.

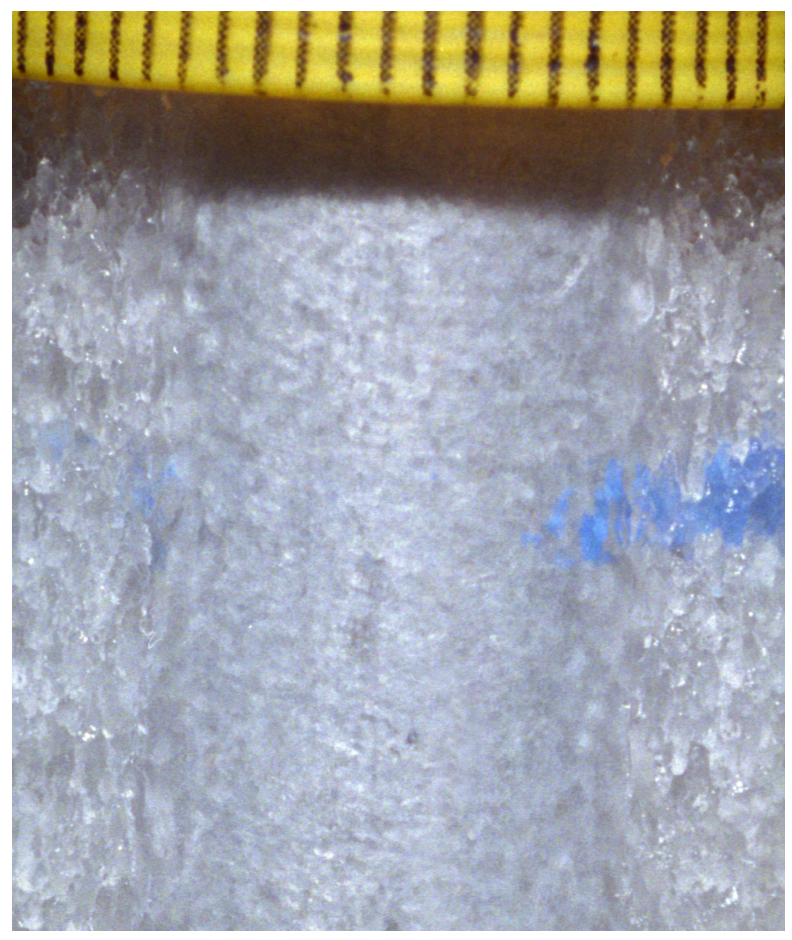

Figure 2: A close-up front view of the leading edge of a wing section, at zero sweep angle, after $1 \mathrm{~min}$ of ice accretion showing a smooth zone centered at the stagnation line and surrounding rough zones with roughness elements of mm size. 6-10-96 Run 6 with $n=0.41$, taken from Ref. 7 .

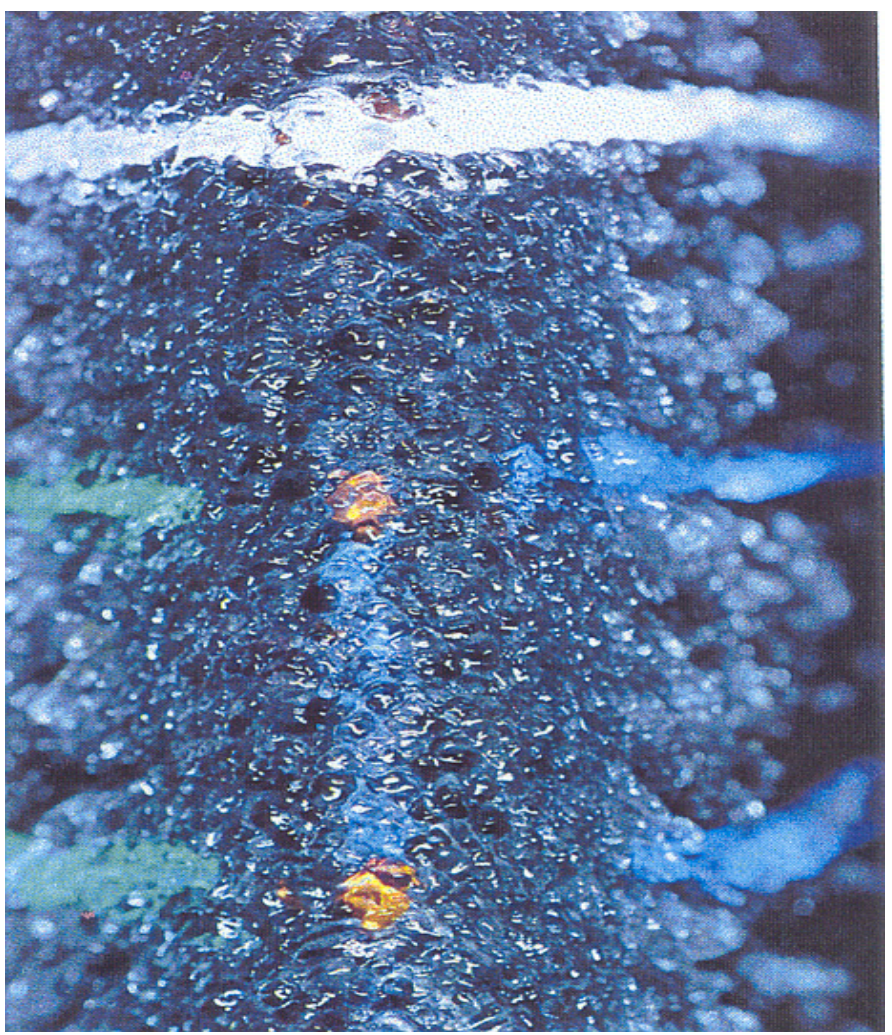

Figure 3: A close-up view of the leading edge of a wing section, at $45^{0}$ sweep angle, after $1 \mathrm{~min}$ of ice accretion showing roughness elements of $\mathrm{mm}$ size covering the entire leading edge region. 6-18-96 Run 3 with $n=0.43$, taken from Ref. 1 .

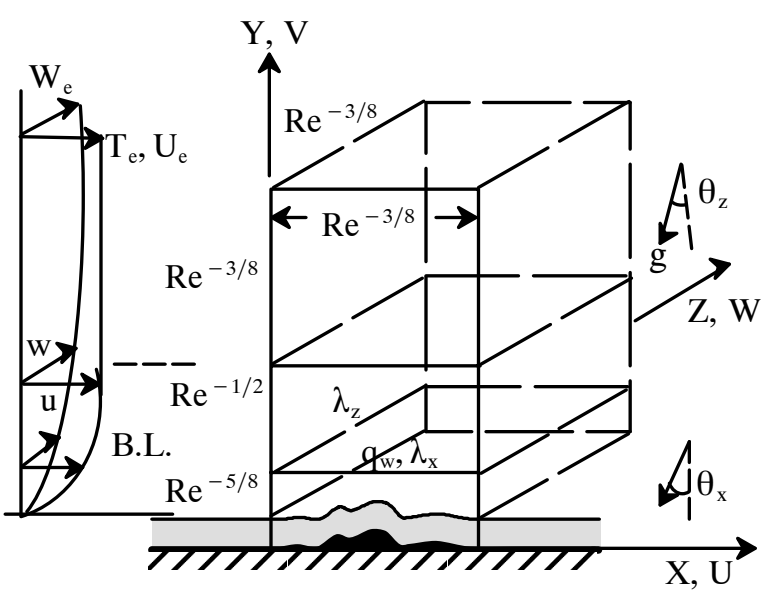

Figure 4: Schematic diagram of the local 3D tripledeck structure with an oncoming steady3D boundary layer base flow. The $\left(\theta_{X}, \theta_{Z}\right)$ are the surface inclination angles w.r.t. the horizon at a given point along the $\mathrm{X}$ and $\mathrm{Z}$ directions. 
(a) Mode 1:
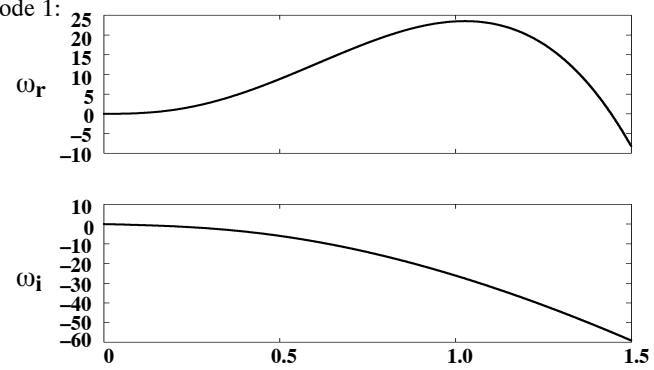

(b) Mode 2:

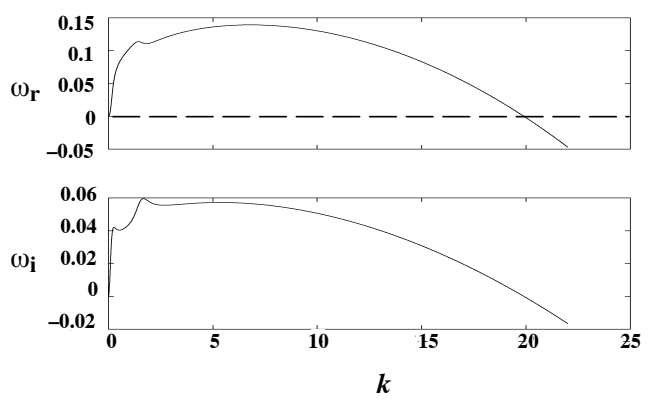

Figure 5: Typical wavelike (mode 1) and broadband (mode 2) instability modes for a linearly unstable case.

(a)

\begin{tabular}{|lcccc|}
\hline $\mathrm{FH}(\mathrm{mm})$ & $\mathrm{kx} 1$ & $\mathrm{Dx} 1(\mathrm{~mm})$ & $\mathrm{kz} 1$ & $\mathrm{Dz} 1(\mathrm{~mm})$ \\
0.0022 & 2.1000 & 0.460249 & 0.0000 & Inf \\
0.0170 & 1.2600 & 0.767081 & 0.0000 & Inf \\
0.0220 & 1.2000 & 0.805435 & 0.0000 & Inf \\
0.0500 & 1.0800 & 0.894928 & 0.0000 & Inf \\
0.2200 & 0.9900 & 0.976285 & 0.0000 & Inf \\
& & & & \\
$\mathrm{FH}(\mathrm{mm})$ & $\mathrm{kx} 2$ & $\mathrm{Dx} 2(\mathrm{~mm})$ & $\mathrm{kz} 2$ & $\mathrm{Dz} 2(\mathrm{~mm})$ \\
0.0022 & 4.6000 & 0.210113 & 0.0000 & Inf \\
0.0170 & 1.7500 & 0.552298 & 0.0000 & Inf \\
0.0220 & 1.6000 & 0.604076 & 0.0000 & Inf \\
0.0500 & 17.000 & 0.056854 & 0.0000 & Inf \\
0.2200 & 12.450 & 0.077632 & 0.0000 & Inf \\
\hline
\end{tabular}

\begin{tabular}{|lcccc|}
\hline $\mathrm{FH}(\mathrm{mm})$ & $\mathrm{kx} 1$ & $\mathrm{Dx} 1(\mathrm{~mm})$ & $\mathrm{kz} 1$ & $\mathrm{Dz} 1(\mathrm{~mm})$ \\
0.0022 & 1.8000 & 0.536957 & 1.8000 & 0.536957 \\
0.0170 & 1.1000 & 0.878656 & 1.1300 & 0.855329 \\
0.0220 & 1.0600 & 0.911813 & 1.0800 & 0.894928 \\
0.0500 & 0.9700 & 0.996414 & 1.0000 & 0.966522 \\
0.2200 & 0.9100 & 1.062112 & 0.9300 & 1.039271 \\
\hline $\mathrm{FH}(\mathrm{mm})$ & $\mathrm{kx} 2$ & $\mathrm{Dx} 2(\mathrm{~mm})$ & $\mathrm{kz} 2$ & $\mathrm{Dz}(\mathrm{mm})$ \\
0.0022 & 3.6000 & 0.268478 & 3.7000 & 0.261222 \\
0.0170 & 1.4500 & 0.666567 & 1.5000 & 0.644348 \\
0.0220 & 1.3700 & 0.705490 & 1.4300 & 0.675889 \\
0.0500 & 1.2600 & 0.767081 & 1.3300 & 0.726708 \\
0.2200 & 8.4500 & 0.114381 & 8.6000 & 0.112386 \\
\hline
\end{tabular}

Figure 6: The most linearly unstable modes at different water film thickness values for (a) zero cross flow (b) non-zero cross flow $\left(\mathrm{W}_{\mathrm{e}}=0.7, \lambda_{\mathrm{Z}}=0.5\right)$ conditions. (a)

$\mathrm{FH}(\mathrm{mm}) \quad \mathrm{kx} 1 \quad \mathrm{kz} 1 \quad \omega_{\mathrm{r} \_a b s 1} \quad \omega_{\mathrm{i} \_a b s 1}$

$\begin{array}{lllll}0.0022 & 2.1000 & 0.4500 & 8.938866 \mathrm{e}-003 & -2.406989 \mathrm{e}-001\end{array}$ $\begin{array}{llllll}0.0170 & 1.2400 & 0.3000 & 3.899485 \mathrm{e}-001 & -1.590248 \mathrm{e}+000\end{array}$ $\begin{array}{llllll}0.0220 & 1.1900 & 0.2900 & 6.814523 \mathrm{e}-001 & -2.211890 \mathrm{e}+000\end{array}$ $\begin{array}{lllll}0.0500 & 1.0700 & 0.2700 & 4.712507 \mathrm{e}+000 & -7.955895 \mathrm{e}+000\end{array}$ $\begin{array}{lllll}0.2200 & 0.9800 & 0.2600 & 2.544874 \mathrm{e}+002-2.305576 \mathrm{e}+002\end{array}$

$\mathrm{FH}(\mathrm{mm}) \quad \mathrm{kx} 2 \quad \mathrm{kz} 2 \quad \omega_{\mathrm{r} \_a b s} \quad \omega_{\text {i_abs2 }}$

$0.0022 \quad 4.4500 \quad 1.14007 .831821 \mathrm{e}-0055.839113 \mathrm{e}-005$ $\begin{array}{llll}0.0170 & 1.6500 & 0.53003 .816821 \mathrm{e}-005 & 2.238419 \mathrm{e}-005\end{array}$

$\begin{array}{llll}0.0220 & 1.5500 & 0.47003 .406755 \mathrm{e}-005 & 1.867217 \mathrm{e}-005\end{array}$

$0.0500 \quad 16.650 \quad 3.35002 .234151 \mathrm{e}-0058.028174 \mathrm{e}-006$

$0.2200 \quad 12.200 \quad 2.45001 .170113 \mathrm{e}-005 \quad 2.090118 \mathrm{e}-006$

(b)

\begin{tabular}{|c|c|c|}
\hline $\mathrm{FH}(\mathrm{mm})$ & $\mathrm{kx} 1$ & $\mathrm{kz} 1 \quad \omega_{\mathrm{r} \_}$abs1 $\quad \omega_{\mathrm{i} \_}$abs1 \\
\hline 0.0022 & 1.800 & $1.8001 .854233 \mathrm{e}-002-4.062437 \mathrm{e}-001$ \\
\hline 0.0170 & 1.100 & $1.1309 .579297 \mathrm{e}-001-3.177195 \mathrm{e}+000$ \\
\hline 0.0220 & 1.060 & $1.0801 .723385 \mathrm{e}+000-4.570972 \mathrm{e}+000$ \\
\hline 0.0500 & 0.970 & $1.0001 .300116 \mathrm{e}+001-1.955354 \mathrm{e}+001$ \\
\hline 0.2200 & 0.910 & $0.9307 .733908 \mathrm{e}+002-7.174143 \mathrm{e}+002$ \\
\hline $\mathrm{FH}(\mathrm{mm})$ & $\mathrm{kx} 2$ & $\omega_{\mathrm{r} \_a b s} 2$ \\
\hline 0.0022 & 3.600 & $3.7009 .182444 \mathrm{e}-0056.589434 \mathrm{e}-005$ \\
\hline 0.0170 & 1.450 & $1.5004 .425115 \mathrm{e}-005 \quad 2.265784 \mathrm{e}-005$ \\
\hline 0.0220 & 1.370 & $1.4303 .893367 \mathrm{e}-0051.851991 \mathrm{e}-005$ \\
\hline 0.0500 & 1.260 & $1.3302 .415656 \mathrm{e}-0059.505031 \mathrm{e}-006$ \\
\hline 0.2200 & 8.450 & $8.6001 .215725 \mathrm{e}-0052.050184 \mathrm{e}-006$ \\
\hline
\end{tabular}

Figure 7:The most linearly unstable modes at different water film thickness for (a) smaller cross flow $\left(\mathrm{W}_{\mathrm{e}}=0.26, \lambda_{\mathrm{Z}}=0.1\right)(\mathrm{b})$ larger cross flow $\left(\mathrm{W}_{\mathrm{e}}=0.7\right.$, $\left.\lambda_{Z}=0.5\right)$ conditions.

(a) \begin{tabular}{lllll|}
\hline $\mathrm{FH}(\mathrm{mm})$ & $\mathrm{kx} 1$ & $\mathrm{Dx} 1(\mathrm{~mm})$ & $\mathrm{kz} 1$ & $\mathrm{Dz} 1(\mathrm{~mm})$ \\
0.0022 & 2.100 & 0.460249 & 0.450 & 2.147827 \\
0.0170 & 1.240 & 0.779453 & 0.300 & 3.221740 \\
0.0220 & 1.190 & 0.812203 & 0.290 & 3.332834 \\
0.0500 & 1.070 & 0.903292 & 0.270 & 3.579711 \\
0.2200 & 0.980 & 0.986247 & 0.260 & 3.717392 \\
\hline (b) & & & & \\
\hline $\mathrm{FH}(\mathrm{mm})$ & $\mathrm{kx} 1$ & $\mathrm{Dx} 1(\mathrm{~mm})$ & $\mathrm{kz} 1$ & $\mathrm{Dz} 1(\mathrm{~mm})$ \\
0.0022 & 2.400 & 0.402717 & 1.950 & 0.495652 \\
0.0170 & 1.550 & 0.623563 & 0.920 & 1.050567 \\
0.0220 & 1.470 & 0.657498 & 0.860 & 1.123863 \\
0.0500 & 1.330 & 0.726708 & 0.740 & 1.306111 \\
0.2200 & 1.230 & 0.785790 & 0.650 & 1.486957 \\
\hline $\mathrm{FH}(\mathrm{mm})$ & $\mathrm{kx} 1$ & $\mathrm{Dx} 1(\mathrm{~mm})$ & $\mathrm{kz} 1$ & $\mathrm{Dz} 1(\mathrm{~mm})$ \\
0.0022 & 0.760 & 1.271739 & 7.650 & 0.126343 \\
0.0170 & 0.570 & 1.695653 & 5.700 & 0.169565 \\
0.0220 & 0.560 & 1.725932 & 5.600 & 0.172593 \\
0.0500 & 0.540 & 1.789856 & 5.400 & 0.178986 \\
0.2200 & 0.530 & 1.823626 & 5.300 & 0.182363 \\
\hline
\end{tabular}

Figure 8: The most linearly unstable wave-like mode at different film thickness for $(a) \mathrm{W}_{\mathrm{e}}=0.26$, $\lambda_{\mathrm{Z}}=0.1(\mathrm{~b}) \mathrm{W}_{\mathrm{e}}=0, \lambda_{\mathrm{Z}}=1.0$ (c) $\mathrm{W}_{\mathrm{e}}=5.0, \lambda_{\mathrm{Z}}=5.0$ conditions. 


(a) \begin{tabular}{|lcccc|}
\hline $\mathrm{FH}(\mathrm{mm})$ & $\mathrm{kx} 2$ & $\mathrm{Dx} 2(\mathrm{~mm})$ & $\mathrm{kz} 2$ & $\mathrm{Dz} 2(\mathrm{~mm})$ \\
0.0022 & 4.4500 & 0.217196 & 1.1400 & 0.847826 \\
0.0170 & 1.6500 & 0.585771 & 0.5300 & 1.823626 \\
0.0220 & 1.5500 & 0.623563 & 0.4700 & 2.056430 \\
0.0500 & 16.650 & 0.058049 & 3.3500 & 0.288514 \\
0.2200 & 12.200 & 0.079223 & 2.4500 & 0.394499 \\
\hline & & & & \\
\hline $\mathrm{FH}(\mathrm{mm})$ & $\mathrm{kx} 2$ & $\mathrm{Dx} 2(\mathrm{~mm})$ & $\mathrm{kz} 2$ & $\mathrm{Dz} 2(\mathrm{~mm})$ \\
0.0022 & 5.3500 & 0.180658 & 2.7000 & 0.357971 \\
0.0170 & 2.1000 & 0.460249 & 0.6600 & 1.464427 \\
0.0220 & 1.9500 & 0.495652 & 0.6400 & 1.510191 \\
0.0500 & 7.3500 & 0.131500 & 14.850 & 0.065086 \\
0.2200 & 5.1500 & 0.187674 & 10.350 & 0.093384 \\
\hline $\mathrm{FH}(\mathrm{mm})$ & $\mathrm{kx} 2$ & $\mathrm{Dx} 2(\mathrm{~mm})$ & $\mathrm{kz} 2$ & $\mathrm{Dz} 2(\mathrm{~mm})$ \\
0.0022 & 1.1300 & 0.855329 & 11.100 & 0.087074 \\
0.0170 & 0.7300 & 1.324003 & 7.7500 & 0.124713 \\
0.0220 & 0.7900 & 1.223446 & 7.7000 & 0.125522 \\
0.0500 & 0.7900 & 1.223446 & 7.8500 & 0.123124 \\
0.2200 & 0.8300 & 1.164484 & 8.4500 & 0.114381 \\
\hline
\end{tabular}

Figure 9: The most linearly unstable broad-bandmode at different film thickness for (a) $\mathrm{W}_{\mathrm{e}}=0.26$, $\lambda_{\mathrm{Z}}=0.1(\mathrm{~b}) \mathrm{W}_{\mathrm{e}}=0, \lambda_{\mathrm{Z}}=1.0(\mathrm{c}) \mathrm{W}_{\mathrm{e}}=5.0, \lambda_{\mathrm{Z}}=5.0$ conditions.

a) 3D flow over a swept wing

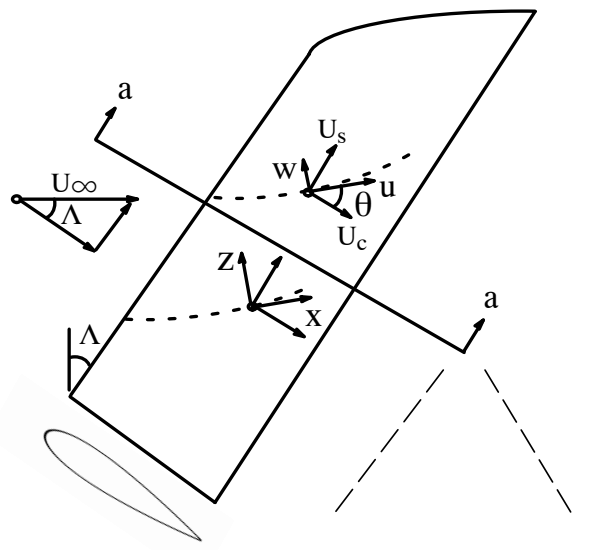

b) leading-edge run-back flow

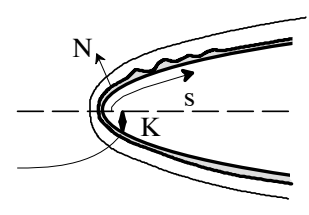

Figure 10: Schematic diagram for the synthesis of the "quasi 3D" flow over a NACA 0012 swept wing. The synthetic flow profile at a given cross section (i.e. line aa) mainly contains a 2D BL flow over a NACA 0012 airfoil with some prescribed spanwise velocity distributions.

(a) \begin{tabular}{lcccc|}
\hline $\mathrm{FH}(\mathrm{mm})$ & $\mathrm{kx} 1$ & $\mathrm{Dx} 1(\mathrm{~mm})$ & $\mathrm{kz} 1$ & $\mathrm{Dz} 1(\mathrm{~mm})$ \\
0.0022 & 0.8800 & 1.098320 & 0.7500 & 1.288696 \\
0.0170 & 0.4500 & 2.147827 & 0.4500 & 2.147827 \\
0.0220 & 0.4200 & 2.301243 & 0.4300 & 2.247726 \\
0.0500 & 0.3600 & 2.684783 & 0.3800 & 2.543479 \\
0.2200 & 0.3000 & 3.221740 & 0.3400 & 2.842712 \\
\hline $\mathrm{FH}(\mathrm{mm})$ & $\mathrm{kx} 1$ & $\mathrm{Dx} 1(\mathrm{~mm})$ & $\mathrm{kz} 1$ & $\mathrm{Dz} 1(\mathrm{~mm})$ \\
0.0022 & 1.7500 & 0.552298 & 1.3100 & 0.737803 \\
0.0170 & 1.0100 & 0.956952 & 0.8300 & 1.164484 \\
0.0220 & 0.9700 & 0.996414 & 0.8000 & 1.208152 \\
0.0500 & 0.8600 & 1.123863 & 0.7400 & 1.306111 \\
0.2200 & 0.7900 & 1.223446 & 0.6900 & 1.400756 \\
\hline $\mathrm{FH}(\mathrm{mm})$ & $\mathrm{kx} 1$ & $\mathrm{Dx} 1(\mathrm{~mm})$ & $\mathrm{kz} 1$ & $\mathrm{Dz} 1(\mathrm{~mm})$ \\
0.0022 & 1.8000 & 0.536957 & 1.8000 & 0.536957 \\
0.0170 & 1.1000 & 0.878656 & 1.1300 & 0.855329 \\
0.0220 & 1.0600 & 0.911813 & 1.0800 & 0.894928 \\
0.0500 & 0.9700 & 0.996414 & 1.0000 & 0.966522 \\
0.2200 & 0.9100 & 1.062112 & 0.9300 & 1.039271 \\
\hline $\mathrm{FH}(\mathrm{mm})$ & $\mathrm{kx} 1$ & $\mathrm{Dx} 1(\mathrm{~mm})$ & $\mathrm{kz} 1$ & $\mathrm{Dz} 1(\mathrm{~mm})$ \\
0.0022 & 1.8000 & 0.536957 & 1.2500 & 0.773218 \\
0.0170 & 1.0700 & 0.903292 & 0.7600 & 1.271739 \\
0.0220 & 1.0200 & 0.947571 & 0.7400 & 1.306111 \\
0.0500 & 0.9300 & 1.039271 & 0.6700 & 1.442570 \\
0.2200 & 0.8600 & 1.123863 & 0.6300 & 1.534162 \\
\hline
\end{tabular}

Figure 11:The most linearly unstable ice roughness elements at various chordwise $\left(s^{*}\right)$ locations (a) $\mathrm{s}^{*}=0.1 \mathrm{~mm}$, (b) $\mathrm{s}^{*}=4 \mathrm{~mm}$, (c) $\mathrm{s}^{*}=8 \mathrm{~mm}$, and (d) $\mathrm{s}^{*}=12.6 \mathrm{~mm}$ with different film thickness.

\begin{tabular}{|c|c|c|c|}
\hline $\mathrm{FH}(\mathrm{mm})$ & $\mathrm{kx} 1$ & kz1 & WR_abs1 \\
\hline 0.0022 & 0.8800 & \multicolumn{2}{|c|}{$0.75007 .900 \overline{4} 97 \mathrm{e}-004-3 . \overline{9} 13777 \mathrm{e}-002$} \\
\hline 0.0170 & 0.4500 & \multicolumn{2}{|c|}{$0.45002 .871825 \mathrm{e}-002-2.055635 \mathrm{e}-001$} \\
\hline 0.0220 & 0.4200 & \multicolumn{2}{|c|}{$0.43004 .799280 \mathrm{e}-002-2.686901 \mathrm{e}-001$} \\
\hline 0.0500 & 0.3600 & \multicolumn{2}{|c|}{$0.38002 .848893 \mathrm{e}-001-7.638027 \mathrm{e}-001$} \\
\hline 0.2200 & 0.3000 & \multicolumn{2}{|c|}{$0.34001 .245243 \mathrm{e}+001-1.380330 \mathrm{e}+001$} \\
\hline $\mathrm{FH}(\mathrm{mm})$ & $\mathrm{kx} 1$ & kz1 & WR abs1 \\
\hline 0.0022 & 1.7500 & \multirow{5}{*}{\multicolumn{2}{|c|}{$\begin{array}{r}1.31009 .914701 e-003-2.570365 e-001 \\
0.83004 .523393 e-001-1.757830 e+000 \\
0.80007 .967976 e-001-2.472327 e+000 \\
0.74005 .644905 e+000-9.263617 e+000 \\
0.69003 .134437 e+002-2.886595 e+002\end{array}$}} \\
\hline 0.0170 & 1.0100 & & \\
\hline 0.0220 & 0.9700 & & \\
\hline 0.0500 & 0.8600 & & \\
\hline 0.2200 & 0.7900 & & \\
\hline $\mathrm{FH}(\mathrm{mm})$ & $\mathrm{kx} 1$ & kz1 & WR abs1 \\
\hline 0.0022 & 1.8000 & \multirow{5}{*}{\multicolumn{2}{|c|}{$\begin{array}{l}1.80001 .854233 \mathrm{e}-002-4.062437 \mathrm{e}-001 \\
1.13009 .579297 \mathrm{e}-001-3.177195 \mathrm{e}+000 \\
1.08001 .723385 \mathrm{e}+000-4.570972 \mathrm{e}+000 \\
1.00001 .300116 \mathrm{e}+001-1.955354 \mathrm{e}+001 \\
0.93007 .733908 \mathrm{e}+002-7.174143 \mathrm{e}+002\end{array}$}} \\
\hline 0.0170 & 1.1000 & & \\
\hline 0.0220 & 1.0600 & & \\
\hline 0.0500 & 0.9700 & & \\
\hline 0.2200 & 0.9100 & & \\
\hline $\mathrm{FH}(\mathrm{mm})$ & $\mathrm{kx} 1$ & $\mathrm{kz} 1$ & WR_abs1 \\
\hline 0.0022 & 1.8000 & 1.2500 & $1.011 \overline{7} 66 \mathrm{e}-002-2 . \overline{5} 83472 \mathrm{e}-001$ \\
\hline 0.0170 & 1.0700 & 0.7600 & $5.002525 \mathrm{e}-001-1.882614 \mathrm{e}+000$ \\
\hline 0.0220 & 1.0200 & 0.7400 & $8.927919 \mathrm{e}-001-2.688304 \mathrm{e}+000$ \\
\hline 0.0500 & 0.9300 & 0.6700 & $6.572208 \mathrm{e}+000-1.090498 \mathrm{e}+001$ \\
\hline 0.2200 & 0.8600 & 0.6300 & $3.803055 e+002-3.778358 e+002$ \\
\hline
\end{tabular}

Figure 12: The growth rates of most linearly unstable ice roughness elements at various chordwise ( $\mathrm{s}^{*}$ ) locations (a) $\mathrm{s}^{*}=0.1 \mathrm{~mm}$, (b) $\mathrm{s}^{*}=4 \mathrm{~mm}$, (c) $\mathrm{s}^{*}=8$ $\mathrm{mm}$, and $(\mathrm{d}) \mathrm{s}^{*}=12.6 \mathrm{~mm}$ with different film thickness. 
(1) Conditions from Ref. 17

\begin{tabular}{|c|c|c|c|c|c|c|c|}
\hline $\begin{array}{c}\text { Test } \\
\text { Date }\end{array}$ & $\mathbf{c}(\mathrm{cm})$ & Run & $\begin{array}{c}\mathrm{T}_{\infty} \\
\left({ }^{\circ} \mathrm{C}\right)\end{array}$ & $\begin{array}{c}\mathrm{V} \infty \\
(\mathrm{m} / \mathrm{s})\end{array}$ & $\begin{array}{c}L W C \\
\mathrm{~g} / \mathrm{m}^{3}\end{array}$ & $\begin{array}{c}\mathrm{n} \\
\text { eqn. (18) }\end{array}$ & $\begin{array}{c}\mathrm{n} \\
\text { eqn. }(19)\end{array}$ \\
\hline $3-21-01$ & 53.3 & 4 & -26.1 & 66.8 & 1.00 & 1.00 & 1.00 \\
\hline $3-9-01$ & 91.4 & 1 & -15.7 & 77.5 & 0.68 & 0.60 & 0.56 \\
\hline $3-19-01$ & 53.3 & 9 & -16.8 & 126.2 & 0.56 & 0.60 & 0.51 \\
\hline $3-20-01$ & 53.3 & 4 & -16.3 & 109.2 & 0.67 & 0.60 & 0.53 \\
\hline
\end{tabular}

(2) Conditions from Ref. 18

\begin{tabular}{|c|c|c|c|c|c|c|c|}
\hline $\begin{array}{c}\text { Test } \\
\text { Date }\end{array}$ & $\mathbf{c}(\mathrm{cm})$ & Run & $\begin{array}{c}\mathrm{T}_{\infty} \\
\left({ }^{\circ} \mathrm{C}\right)\end{array}$ & $\begin{array}{c}\mathrm{V}_{\infty} \\
(\mathrm{m} / \mathrm{s})\end{array}$ & $\begin{array}{c}L W C \\
\mathrm{~g} / \mathrm{m}^{3}\end{array}$ & $\begin{array}{c}\mathrm{n} \\
\text { eqn. (18) }\end{array}$ & $\begin{array}{c}\mathrm{n} \\
\text { eqn. }(19)\end{array}$ \\
\hline $11-13-00$ & 53.3 & 7 & -19 & 67 & 0.99 & 0.77 & 0.73 \\
\hline $3-19-01$ & 53.3 & 6 & -10 & 67 & 1.00 & 0.40 & 0.37 \\
\hline $3-20-01$ & 53.3 & 1 & -7 & 67 & 1.00 & 0.28 & 0.26 \\
\hline $11-13-00$ & 53.3 & 8 & -27 & 67 & 0.99 & 1.00 & 1.00 \\
\hline
\end{tabular}

Figure 13: Test conditions and results for comparing the freezing fraction calculation obtained from eqn. (18) ${ }^{17-18}$ and eqn. (19). 


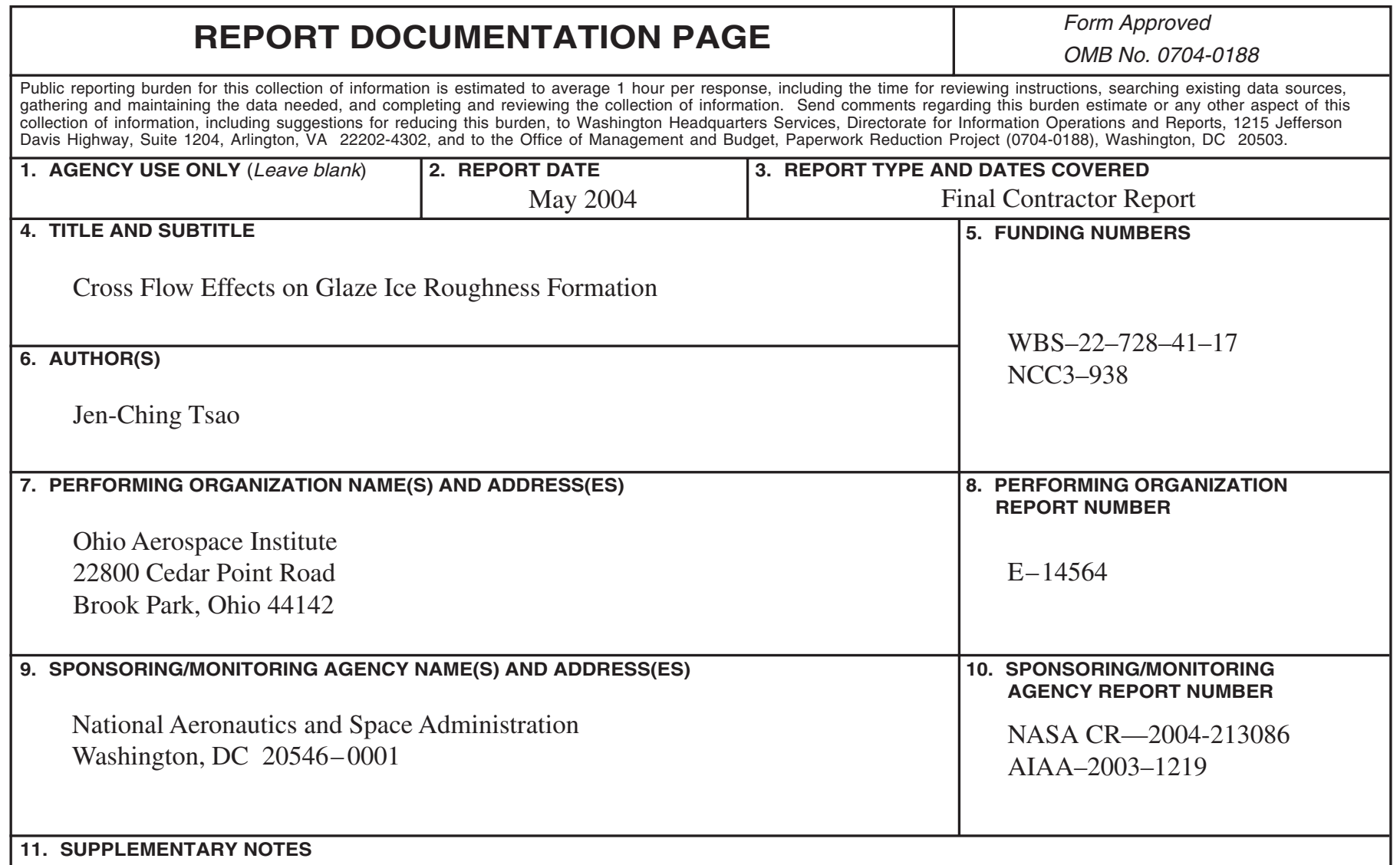

Prepared for the 41st Aerospace Sciences Meeting and Exhibit sponsored by the American Institute of Aeronautics and Astronautics, Reno, Nevada, January 6-9, 2003. Project Manager, Mark G. Potapczuk, Turbomachinery and Propulsion Systems Division, NASA Glenn Research Center, organization code 5840, 216-433-3919.

12a. DISTRIBUTION/AVAILABILITY STATEMENT

12b. DISTRIBUTION CODE

Unclassified - Unlimited

Subject Categories: 03 and 34

Distribution: Nonstandard

Available electronically at http://gltrs.grc.nasa.gov

This publication is available from the NASA Center for AeroSpace Information, 301-621-0390.

13. ABSTRACT (Maximum 200 words)

The present study examines the impact of large-scale cross flow on the creation of ice roughness elements on the leading edge of a swept wing under glaze icing conditions. A three-dimensional triple-deck structure is developed to describe the local interaction of a 3-D air boundary layer with ice sheets and liquid films. A linear stability analysis is presented here. It is found that, as the sweep angle increases, the local icing instabilities enhance and the most linearly unstable modes are strictly three dimensional.

\begin{tabular}{|c|c|c|}
\hline \multicolumn{3}{|l|}{$\begin{array}{l}\text { 14. SUBJECT TERMS } \\
\text { Glaze ice roughness }\end{array}$} \\
\hline $\begin{array}{l}\text { 17. SECURITY CLASSIFICATION } \\
\text { OF REPORT } \\
\text { Unclassified }\end{array}$ & $\begin{array}{l}\text { 18. SECURITY CLASSIFICATION } \\
\text { OF THIS PAGE } \\
\text { Unclassified }\end{array}$ & $\begin{array}{l}\text { 19. SECURITY CLASSIFICATION } \\
\text { OF ABSTRACT } \\
\text { Unclassified }\end{array}$ \\
\hline
\end{tabular}

NSN 7540-01-280-5500 

